\title{
LMO1 wt Allele
}

National Cancer Institute

\section{Source}

National Cancer Institute. LMO1 wt Allele. NCI Thesaurus. Code C91264.

Human LMO1 wild-type allele is located in the vicinity of $11 \mathrm{p} 15$ and is approximately $44 \mathrm{~kb}$ in length. This allele, which encodes rhombotin-1 protein, plays a role in the modulation of gene transcription. Translocation involving the gene is associated with T-cell acute lymphoblastic leukemia. 